\title{
The Development Of Guidance and Kit Innovative Chemistry Lab Based on PBL (Problem Based Learning) According to Curriculum 2013 For Class 12th Of Even Semester
}

\author{
Jusmasari Harahap \\ Departement of Chemistry Educatiom \\ Universitas Negeri Medan \\ Medan, Indonesia \\ *Corresponding autors: harahap.jusmasari@gmail.com
}

\author{
Nurfajriani \\ Departement of Chemistry Educatiom \\ Universitas Negeri Medan \\ Medan, Indonesia
}

\author{
Ramlan Silaban \\ Departement of Chemistry Educatiom \\ Universitas Negeri Medan \\ Medan, Indonesia
}

\begin{abstract}
This study aims to develop guidance and kit innovative chemistry lab based on PBL (Problem Based Learning) according to curriculum 2013 for class 12th of Even Semester which feasible empirically according to expert (chemistry lecturer) and chemistry teacher. The guided practicum and the kit guide integrate the 5 stages of the PBL learning model at each practicum. This PBL model enables learners to understand the facts and concepts of science. Research this development using ADDIE model. This research is only done up to the expert and teacher level. Validasi experts and teachers are conducted to assess the guides in terms of content, language, presentation, and chart and kit feasibility. Data validation results are analyzed descriptively qualitative. Guided validation results show 3.77 With very valid criteria And the validation kit shows 3.70 with very valid criteria. As conclusions the guide and kit the developed lab are feasible according to experts and chemistry teachers to proceed at a later stage.
\end{abstract}

Keywords-component; Guidance, Kit, Problem Based Learning, 2013, Chemistry lecturer, Chemistry teacher

\section{INTRODUCTION}

The 2013 curriculum is a curriculum that introduces a scientific approach or a scientific approach in learning as a process of building knowledge, skills, and attitudes [1]. The 2013 curriculum also develops two learning modes: direct teaching and indirect teaching. Where are the characteristics of learning within kuriku 1 um 2013 include: interactive and inspiring, fun, challenge, and motivate students to participate actively, contextual and collaborative, provide enough space for innovation, creativity, and independence of the students;and in accordance with the students' physical, psychological talents, interests, abilities and development.

Chemistry is one of the subjects listed in the 2013 curriculum. Chemistry as part of Natural Sciences is obtained and developed based on experiments to find answers to questions of what, why, and how natural phenomena are specifically related to composition, structure, nature, transformation, dynamics and energetics of substances. The laboratory is one of the most important sources of chemical learning to provide real experience to learners, as one of the supporting factors of learning [2] . Chemistry learning which is followed by practicum can understand abstract chemical concepts, because with practicum abstract concepts can be understood to be concrete concepts by students [3] . Expertise at the time of practicum plays an important role to explore the insights of chemistry related to the subject learned in class [4] .

Based on the results of interviews and preliminary survey with chemistry teachers at high school who are in Rantauprapat, obtained the results of interviews and surveys that the problems associated with the learning of chemistry that is the result of learning chemistry seen from the results of study persemester still low and chemistry subject teachers rarely do the learning using the peraktikum method for the following reasons: it is not a special chemical laboratory; inadequate tools and chemicals; the lack of availability of practical guidance that is in line with the 2013 curriculum. 
Based on research conducted by Nurfajriani teaching materials in the context of learning is one important component because teaching material is a component that must be studied, examined, studied, and used as material that must be mastered by students as well as can provide guidance to learn and is wrong one factor that can strengthen student motivation to learn [5]. A practical guide is a guideline for the implementation of the practicum used by the practitioner in practicum implementation so that the practicum guide is included in the teaching materials [6]. Mulyono stated that the chemical practicum guide can influence student learning outcomes, this is evidenced by the findings obtained in the learning process using practicum because: (1) practicum modules can be read / absorbed and understood by most students; (2) the practicum module may be implemented or applied in the student's residence environment, and (3) the student's performance may be assessed by the relevant chemistry teacher within the assessment timeframe [7] .

PBLs are described as consruktivist teaching models based on the assumption that learning is the result of cognitive and social interactions originating from problem-focused environments [8]. Barrows stated that the main characteristics of PBL are as follows: learning is student-centered, learning is formed in small groups of students, teachers must act as moderators and facilitators, the problem provides motivation for learning and organizational focus, problems provide a basis for progress in clinical problem solving skills, and Independent learning allows the acquisition of new information [9] .

Media in accordance with the practical guide that will researchers develop the Kit media. The kit is a simple practicum tool so students can experiment in groups in the classroom and this kit can be used to develop the domain of cognitive thinking, effective and psychomotor [10]. Eko's research also presents a simple set of practical tools that are easy to find and use for learning called chemistry kits $(C K)$ as an easy step to do a small-scale practicum but still holds the concept [11].

\section{METHOD}

This research has been conducted at SMA N 1 Bilah Hilir on TP. 2017/2018 is October 2017- March 2018. In this time interval includes: analyze, design, construct, develop, guide and kit praktikun chemicals present on the subjects of chemistry class XII SMA / MA Semester accordance with the curriculum of 2013. Samples used in this study are two high school chemistry teachers, two chemistry lecturers who are actively teaching and mastering the guides and practice kits. This research type is research development (development research). The development research model that will be used in this study is the ADDIE model. In this study only done until the product validation stage by expert validator. The research procedure includes the following stages: (1) In the analysis phase, needs analysis is done by giving a questionnaire to the teacher related to the teacher needs related to the implementation of the lab work in school. Furthermore, it analyzed the chemistry practicum guide used in the school and the practicum guide that has been developed by previous research to know the level of conformity of the practicum guide with BSNP. Then an analysis of the syllabus of chemistry curriculum 2013 class XII Semester Even, as a reference to develop guides and practice kits. (Analysis Stage). (2) Formulate the expected learning objectives from chemistry lesson class XII even semester and design an innovation of chemistry learning through practicum activities by integrating PBL model. At this stage the research instrument was also made consisting of a needs analysis instrument, guide analysis, guide validation and practicum kit, practicum observation observation sheet, student attitude conservation sheet, student response questionnaire, and student science process skills test tool after using the guide and kit practice. (Design Stage). (3) Develop guides and practice kits in accordance with the design analysis prepared in the previous stages. The guides and the practicum kits that have been developed are then assessed by expert validators consisting of two chemistry lecturers from Medan State University, two chemistry teachers. The validated product is subsequently revised based on the expert validator's repair suggestion. (Development Stage).

\section{RESULTS AND DISCUSSION}

Before carrying out the guidance development, the researcher conducted an analysis of the high school / practicum chemistry practicum guide for grade XII even semester that was used in schools with different publishers, namely guide I, guide II and guide III. Analysis of laboratory chemistry guidance is conducted to determine the level of eligibility of the guidance both from the feasibility of the content, language feasibility, feasibility of presentation and feasibility of kegrafikan in accordance with BSNP standards that have been modified. The result of the guidance lab study guide is shown in Figure 1.

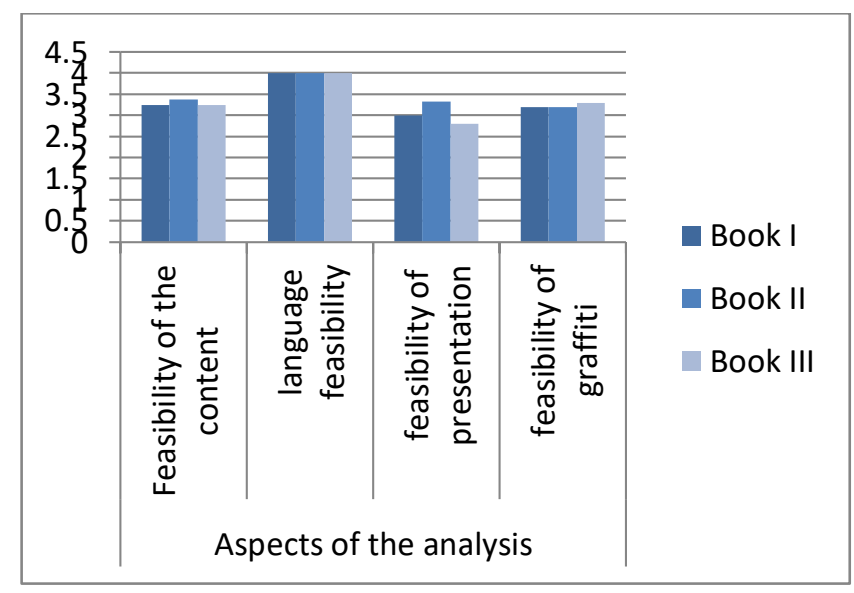

Fig 1. Preliminary workshop analysis result based on BSNP 
The results of the analysis of class XII chemistry grade semum guides based on BSNP that have been analyzed indicate that the guidance used in the school is valid and feasible to be used. But there are some parts of the textbook that need to be revised and the addition of components according to BSNP. After analysis, the shortcomings of the previously analyzed guiding components were developed. After carrying out the guidance and supporting media guidance dikembangka $\mathrm{n}$, at implement the next step.

The next stage is the validation stage. At this stage, a PBLbased chemicals practice guide based on the developed 2013 curriculum is validated using the modified standard of National Education Standards Agency (BSNP). The analysis was carried out by the number of respondents in 2 Medan State University chemistry lecturers (UNIMED) and 2 chemistry teachers. The guides of the developed chemistry lab are assessed on the basis of four feasibility standards according to BSNP, which are content feasibility, language feasibility, feasibility of presentation and feasibility of kegrafikan. Chemical practicum guide was analyzed by responding in the form of check list with assessment $4=$ strongly agree; 3 = agree; 2 = less agree; $1=$ disagree.

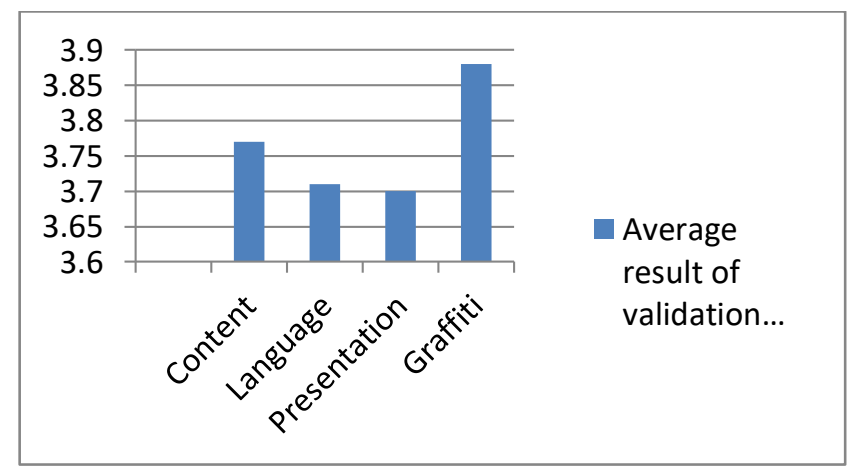

Fig 2. Validation results of the practicum guide produced by the

$$
\text { development }
$$

The result of chemical lab guide study developed based on BSNP questionnaire that has been modified in accordance with the chemistry practicum guide includes content feasibility, language feasibility, feasibility of presentation and feasibility of kegrafikan shows that the average value of 3.77 means valid and does not need to be revised so it is feasible to use . In detail the analysis of four aspects of BSNP can be seen in the table below:
TABLE 1 . Feasibility Validation Results Contents Guidance of Chemical Practicum

\begin{tabular}{|c|c|c|c|c|c|c|c|c|}
\hline \multirow{2}{*}{ Aspect } & \multirow{2}{*}{ Indicator } & \multicolumn{4}{|c|}{ Validator } & \multirow[t]{2}{*}{$\begin{array}{l}\text { Total } \\
\text { Score }\end{array}$} & \multirow[t]{2}{*}{ Averag } & \multirow[t]{2}{*}{ Criteris } \\
\hline & & l & 2 & 3 & 4 & & & \\
\hline \multirow{5}{*}{$\begin{array}{l}\text { Feasibility of } \\
\text { Content }\end{array}$} & $\begin{array}{l}\text { Organizing } \\
\text { thechemistrylabguidg }\end{array}$ & 4.00 & 4.00 & 4.00 & 4.00 & 12 & 4.00 & SV \\
\hline & Material covergge & 3.33 & 3.67 & 3.33 & 3.67 & 14 & 3.50 & SV \\
\hline & Concept truth & 3.75 & 4.00 & 4.00 & 3.75 & 15.5 & 3.87 & SV \\
\hline & $\begin{array}{l}\text { The contents of the } \\
\text { chemistrylab guide }\end{array}$ & 4.00 & 3.50 & 3.50 & 4.00 & 15 & 3.75 & SV \\
\hline & $\begin{array}{l}\text { Workshop guide } \\
\text { innovation }\end{array}$ & 3.50 & 3.50 & 4.00 & 4.00 & 15 & 3.75 & SV \\
\hline & ptal Score & & & & & 71.50 & 3.77 & SV \\
\hline
\end{tabular}

TABLE 2. Validation Validation Results Language Guidance of Chemical Practicum

\begin{tabular}{|c|c|c|c|c|c|c|c|c|}
\hline \multirow{2}{*}{ Aspect } & \multirow{2}{*}{ Indicator } & \multicolumn{4}{|c|}{ Validator } & \multirow{2}{*}{$\begin{array}{l}\text { Total } \\
\text { Score }\end{array}$} & \multirow{2}{*}{ Averag } & \multirow{2}{*}{ Criteris } \\
\hline & & 1 & 2 & 3 & 4 & & & \\
\hline \multirow{4}{*}{$\begin{array}{l}\text { Language } \\
\text { Feasibility }\end{array}$} & $\begin{array}{l}\text { In accordance with } \\
\text { the development of } \\
\text { learners }\end{array}$ & 3.00 & 4.00 & 3.50 & 3.50 & $2: 00$ & 3.50 & SV \\
\hline & $\begin{array}{l}\text { Aspects of clarity of } \\
\text { sentence and level of } \\
\text { readability }\end{array}$ & 4.00 & 4.00 & 3.50 & 4.00 & 15.50 & 3.87 & SV \\
\hline & Aspects of Writing & 3.00 & 4.00 & 4.00 & 4.00 & 3.00 & 3.75 & SV \\
\hline & $\begin{array}{l}\text { Aspects of langugage } \\
\text { use, terms and } \\
\text { symbols }\end{array}$ & 4.00 & 4.00 & 4.00 & 3.50 & 15.50 & 3.87 & SV \\
\hline \multicolumn{2}{|r|}{ Total Score } & & & & & 60.00 & 3.71 & SV \\
\hline
\end{tabular}

TABLE 3 . Feasibility Validation Result of Presentation of Chemical

\begin{tabular}{|c|c|c|c|c|c|c|c|c|}
\hline \multicolumn{9}{|c|}{ Practicum Guide } \\
\hline \multirow{2}{*}{ Aspect } & \multirow{2}{*}{ Indicator } & \multicolumn{4}{|c|}{ Validator } & \multirow[t]{2}{*}{$\begin{array}{l}\text { Total } \\
\text { Score }\end{array}$} & \multirow[t]{2}{*}{ Averag } & \multirow[t]{2}{*}{ Criteris } \\
\hline & & 1 & 2 & 3 & 4 & & & \\
\hline \multirow{5}{*}{$\begin{array}{l}\text { Feasibility of } \\
\text { Presentation }\end{array}$} & $\begin{array}{l}\text { Chemical practicum } \\
\text { ggide component }\end{array}$ & 3.67 & 3.67 & 3.33 & 4.00 & 14.67 & 3.67 & SV \\
\hline & $\begin{array}{l}\text { Aspects of } \\
\text { presentation of } \\
\text { chemistrylab work }\end{array}$ & 4.00 & 3.00 & 4.00 & 4.00 & 3.00 & 3.75 & SV \\
\hline & $\begin{array}{l}\text { Lavel of practicm } \\
\text { implementation }\end{array}$ & 4.00 & 4.00 & 4.00 & 4.00 & $16: 00$ & 4.00 & SV \\
\hline & Evaluation & 3.33 & 3.67 & 3.67 & 3.33 & $2: 00$ & 3.50 & SV \\
\hline & tal Score & & & & & 59.67 & 3.70 & SV \\
\hline
\end{tabular}


TABLE 4 . Results of Validation of Challenge of Challenging of Chemical Practicum Guidance

\begin{tabular}{|c|c|c|c|c|c|c|c|c|}
\hline \multirow[t]{2}{*}{ Aspect } & \multirow[t]{2}{*}{ Indicator } & \multicolumn{4}{|c|}{ Validator } & \multirow[t]{2}{*}{$\begin{array}{l}\text { Total } \\
\text { Score }\end{array}$} & \multirow[t]{2}{*}{ Averag } & \multirow[t]{2}{*}{ Criteria } \\
\hline & & 1 & 2 & 3 & 4 & & & \\
\hline \multirow{3}{*}{$\begin{array}{l}\text { Channel } \\
\text { Feasibility }\end{array}$} & Book size & 4.00 & 4.00 & 4.00 & 4.00 & $16: 00$ & 4.00 & $\overline{S V}$ \\
\hline & $\begin{array}{l}\text { Leather } \\
\text { book design }\end{array}$ & 3.75 & 4.00 & 3.50 & 3.50 & 14.75 & 3.69 & SV \\
\hline & $\begin{array}{l}\text { Design book } \\
\text { content }\end{array}$ & 4.00 & 4.00 & 4.00 & 4.00 & $16: 00$ & 4.00 & SV \\
\hline \multicolumn{2}{|c|}{ Total Score } & & & & & 46.75 & 3.88 & $\overline{\text { SV }}$ \\
\hline
\end{tabular}

Based on the validation results obtained that the development of practicum in doing research valid and feasible in use. This is in line with the research by Purnama et al. That the development of teaching materials can improve the learning and character of students [12]. While Rosmalinda developed a practicum guide by integrating PBL models [13]. After the validation of the guide, validation of the media used is the kit using the standard instrument of Kemendikbud. The level of feasibility of a chemical practicum kit developed based on the instruments from the modified Ministry of Education and Culture is shown in Table 5 .

TABLE 5. Results of Validation of Chemical Practicum Kit

\begin{tabular}{|c|c|c|c|c|c|c|c|c|c|}
\hline \multirow{2}{*}{ No } & \multirow{2}{*}{$\begin{array}{l}\text { Aspects of Eligibility } \\
\text { of the Kit Peraltikum }\end{array}$} & \multirow{2}{*}{$\begin{array}{l}\text { Date } \\
\text { Item } \\
\end{array}$} & \multicolumn{4}{|c|}{ Validator } & \multirow{2}{*}{$\begin{array}{l}\text { Total } \\
\text { Score }\end{array}$} & \multirow{2}{*}{ Avergy } & \multirow{2}{*}{ Criteris } \\
\hline & & & 1 & 2 & 3 & 4 & & & \\
\hline 1 & $\begin{array}{l}\text { Linkage with the subject } \\
\text { metter }\end{array}$ & 2 & 8 & 8 & 8 & 8 & 32 & 4.00 & SV \\
\hline 2 & The value of eduction & 2 & 8 & 7 & 7 & 8 & 30 & 3.75 & SV \\
\hline 3 & Equipment resistance & 2 & 8 & 8 & 8 & 7 & 31 & 3.88 & SV \\
\hline 4 & The accuracy of the tool & 2 & 7 & 7 & 7 & 7 & 28 & 3.50 & SV \\
\hline 5 & Efficiencytool & 2 & 8 & 7 & 8 & 6 & 29 & 3.63 & SV \\
\hline 6 & Security for leamers & 1 & 3 & 4 & 4 & 3 & 14 & 3.50 & SV \\
\hline 7 & Aesthetics & 1 & 3 & 3 & 3 & 4 & 13 & 3.25 & SV \\
\hline 8 & Box kit & 2 & 8 & 7 & 8 & 7 & 30 & 3.75 & SV \\
\hline & Total number & 14 & 53 & 51 & 53 & 50 & 207 & 3.70 & SV \\
\hline
\end{tabular}

The results of the validation of the practicum kit that has been developed referring to the instrument from the BSNP that is modified by four validators has an average value of 3 , 70 meaning that it is very valid and does not need to be revised so that it is feasible to used. Damayati's research to develop stoichiometric kit media as learning media can improve students' concept understanding [14] .

\section{CONCLUSION}

Based on the results of research that has been done then it can be taken conclusion that is:

1. Practical guides used in schools so far have not fully fulfilled the BSNP criteria, there are several

2. components of the guidance that need to be developed.

3. Guidance of innovative chemistry based on PBL according to curriculum of 2013 class XII SMA /MA even semester developed valid according to BSNP standard with average value 3,77 .

4. Chemical practice kits developed are valid in accordance Kemendikbud with average value 3.70.

\section{References}

[1] Kementerian Pendidikan dan Kebudayaan Republik Indonesia, (2013), Peraturan Menteri Pendidikan dan Kebudayaan Republik Indonesia Nomor 69 Tahun 2013 tentang Kerangka Dasar dan Struktur Kurikulum Sekolah Menengah Atas/Madrasah Aliyah. Jakarta

[2] Darsana, I.W., Sadia, I.W., Tika, I.N., (2014). Analisis Standar Kebutuhan Laboratorium Kimia dalam Implementasi Kurikulum 2013 Pada SMA Negeri Di Kabupaten Bangli, e-Journal Program Pascasarjana Universitas Pendidikan Ganesha, 4.

[3] Mukhtar, Z., Emiliya, R., Silaban, R., (2015). Pengembangan Penuntun Praktikum Model Discovery Dan Project Based Learning Pada Pembelajaran Asam Dan Basa Di Sma Kelas Xi, Jurnal Tabularasa, 12(3).

[4] Altun, E., Demirdag, B., Burak, F., Alev, A., Iker, C., (2009). Developing an interactive virtual chemistry laboratory enriched with constructivist learning activities for secondary schools. Procedia Social and Behavioral Sciences 1 (2009)

[5] Nurfajriani \& Dyah T,R., (2016), Pengembangan Modul Pembelajaran IPA Berbasis Learning Cycle $5 E$ pada materi Zat Aditif dalam Makanan, Jurnal Pendidikan Kimia, 8(3)

[6] Depdiknas., (2003). Undang-Undang Replubik Indonesia Nomor 20 tahun 2003 Tentang Sitem Pendidikan Nasional. Jakarta: Depdiknas RI

[7] Mulyono, (2005). Pengembangan dan Implementasi Model Praktikum Kimia Berbasis Lingkungan Tempat Tinggal Siswa pada SMU di Bandung, Jurnal Pengajaran MIPA, 6(1)

[8] Greeno JG, Collins AM, Resnick L (1996). Cognition and Learning. In: Calfee RC, Berliner DC (eds) Handbook of Educational Psychology, New York: Macmillan.

[9] Barrows, H. S., (1996). Problem-Based Learning in Medicine and Beyond: A Brief Overview. New Directions for Teaching and Learning, 1996. http://dx.doi.org/10.1002/tl.37219966804

[10] Juwita, R., (2015), Pengembangan Kit Elektrokimia Kelas XII SMA. Jurnal Pelangi, 8(1). 
[11] Eko, (2010). Penggunaan Bahan Kimia Berumah Tangga Untuk Eksperimen Kimia (Sebagai Alternatif Praktikum Kimia di SMA). Jurnal Program Studi Kimia UNYI, 2(2).

[12] Purnama, D., Ajat,S., dan Nurfajriani., (2017), Pengembangan Modul Kimia Larutan yang Inovatif Terinternalisasi Karakter Untuk Meningkatkan Hasil Belajar dan Karakter Siswa, Jurnal Taularasa PPS Unimed, 14(2)

[13] Rosmalinda, D., Rusdi, M., dan Hariyadi, B., (2013), Pengembangan Modul Praktikum Kimia SMA Berbasis PBL (Problem Based Learning), Jurnal Edu Sains, 2(3)

[14] Damayanti, N.P.S \& Rusmini., (2017). Pengembangan Paduan Praktikum Kimia Kelas X SMA Semester II Berbasis Inkuiri Terbimbing Berdasarkan Kurikulum 2013. Unesa Journal Of Chemical Education, 6(1) 